\title{
First farmers
}

Keywords: archaeobotanical remains, evolution, hunter gatherers, foragers, farming

\section{Introduction}

What problem, within a number of forager economies that existed around the world, was solved, by domesticating plants and animals? This is the question that should occur to anyone reading this recently published research ${ }^{1}$ reporting that there were significant genetic changes in the direction domestication many thousands of years before the onset of the Neolithic.

\section{Look at the model as presented}

The researchers traced the timeline of crop evolution in these areas by analyzing the evolving gene frequencies of archaeologically uncovered plant remains. Wild plants contain a gene which enables them to spread or shatter their seeds widely. When a plant begins to be gathered on a large scale, human activity alters its evolution, changing this gene and causing the plant to retain its seeds instead of spreading them thus adapting it to the human environment and eventually agriculture. Professor Allaby and his colleagues made calculations from archaeobotanical remains of crops mentioned above that contained 'non-shattering' genes the genes which caused them to retain their seeds and found that human gathering had already started to alter their evolution millennia before previously accepted dates.

Now, when you read this line in that article, "human activity alters its evolution, changing this gene and causing the plant to retain its seeds instead of spreading them thus adapting it to the human environment and eventually agriculture" you see there is a significant conceptual blind spot. The way this is written indicates that the researchers where assuming that the process they were describing was gradual domestication. They were thinking like farmers: assuming "the human environment and eventually agriculture": the implication is that the plant is becoming pre-adapted to management within a farming system. The problem with this is that the hunter-gatherers who were harvesting wild grain did not necessarily desire to become farmers. They did not even conceive that such an economy was even possible. They simply had become accustomed to collecting tons of an annual wild grain and storing it so that they could have enough to eat through the winter dry season that followed. They had adapted to the risks in such seasonal variation in food resources by becoming "delayed return" foragers. Hunter-gatherer "immediate return" economies are associated with levels of mobility calibrated by social factors, although this tends to result in low land use intensity forestalling over-hunting and over-harvesting in any one part of their annual round of activities. Sedentary hunter-gatherers, on the other hand, tend to have economies based on delayed return. They were harvesting and processing for long term storage.

Sedentism itself was a human adaptation to the ecological conditions that were characterized by massive pulses of energy-dense foods (salmon runs, wild annual cereal all ripening at once, massive game migrations funneling through a limited route, etc) followed by a dry or cold season of food scarcity. Even in the Kalahari, I found the hunter-gatherers caching stores of wild nuts after an especially bountiful harvest and they also stored dried meat. Wild tubers and

\footnotetext{
'https://www.eurekalert.org/pub_releases/2017-10/uow-cet102317.php
}

Volume 2 Issue I - 2017

\section{Helga Vierich \\ Department of Anthropology, Yellowhead Tribal College, Canada}

Correspondence: Helga Vierich, Department of Anthropology, Yellowhead Tribal College, Canada, Email hvierich@gmail.com

Received: November 02, 2017 | Published: November 07, 2017

onions which were not eaten within two days were casually replanted in the middens behind the camping site. Women joked about this as their way of "farming" - and indeed, on gathering trips, they would detour past old campsites to harvest plantations of tasty root crops.

This led to a pattern of unconscious selection pressure. whereby the plants least desirable to humans the bitterest melons, the seeds difficult to dislodge from the panicle (non-shattering rachis), the least juicy berries - are left behind by the gatherers and thus are the ones that reseed the next year and thus eventually these are the ones that come to dominate wild stands (this is reflected in the "selection coefficients" for "non-shattering" discussed in the posted article). The wild plant was not being adapted to "eventually" being an agriculturally managed species. The unconscious selection exerted by the prolonged attacks (harvesting activities) by humans, were altering the wild plant's reproductive activities.

The plants with a non-shattering rachis were essentially now at a reproductive advantage, since they were left behind by the human gatherers. These seeds which carry genes for non-shattering, constitutes more and more for next year's wild stand of the cereal. What was happening was the result of the plant adapting to human predation by becoming harder and harder to gather. This same process is currently on-going due to harvesting of wild rice in North America. I saw women harvesting stands of wild millet the same way in Africa. They take advantage of the "shattering" quality - a way for the plant drops seeds, with any disturbance. Gatherers, by brushing the mature seeds (ready to be shattered) into a container, can harvest massive amounts in a few weeks as the wild stand matures. In the case of wild rice the plants are brushed gently so the seed drops into the canoe. ${ }^{2}$ In Africa, women spread a leather bag under the plants or else walked through the wild stand brushing seeds into a flat basket.

So, to repeat the question: what problem, within a forager economy was solved, by domesticating plants and animals? Over-harvesting can reduce the ability of favored species to reproduce successfully. It can also lead to a pattern of unconscious selection pressure whereby the plants least desirable to humans the bitterest melons, the seeds difficult to dislodge from the panicle (non-shattering rachis), the least juicy berries - are the ones that come to dominate wild stands (this is reflected in the "selection coefficients" discussed in the posted article). The danger of over-harvesting of major food species is, therefore, typical of the heightened risk associated with delayed return economies. Once too many of the major food species (especially plants) have been influenced by human harvesting, to the point where a lot of them are no longer tasty or no longer EASY to harvest or declining

\footnotetext{
${ }^{2}$ https://www.youtube.com/watch?v=X8R1p9mMq_I
} 
locally, That is the Triggering Point. Either this problem gets solved by abandoning the village and the entire infrastructure (granaries) vested therein or the hunter-gatherers develop a technological or management fix.

So they invent sickles to cut the plants stalk by stalk and bundle them homeward where a newly invented threshing floor awaits. And in the case of bitter melons or other plants with genomes selected unconsciously by the methods of the human harvesters, the only option for a sedentary population is to select seeds or cuttings of the preferred plants and deliberately promote their propagation. More people can be supported by an acre of pioneering annual cereal grasses (rice, oats, barley, wheat, millet, sorghum, maize) than by an acre of wild mixed secondary growth and certainly more than young sub-climax forest, even if some of the trees produce edible fruit or nuts. Clearing away competing species and creating patches of land for this is a natural extension of what hunter-gatherers already do. Presto, farming, at least, simple slash and burn horticulture or forest gardening, emerges.

As may have been the case throughout much of Eurasia, farming people tended to settle on major water points. This even seems to have been typical of the period before there was any actual domestication of plants and animals, the so-called Mesolithic, as some forager groups became sedentary on a reduced land base by increasing the intensity of their ecosystem engineering. Annual grasses are essentially pioneering "weeds" adapted to colonizing disturbed soils. Pioneering plants come in two kinds:

a. The annuals that invade fertile soils laid bare by floods, fires, burrowing animals or recent volcanic activity; and those which tend to get established in relatively infertile soils

b. Perennials whose roots are deeper, more involved with the microbial and fungal networks and which tend to be replaced by more woody species as soil regeneration proceeds.
The cereal and root crops that humans have domesticated fall within the first category: they are annuals adapted to get a flush of rapid productivity out of fertile soils. Even stable climax steppe or prairie climaxes are no match for pioneering annuals in yield. But this higher productivity is short lived and comes at a cost.

After a year or two of cultivation, soil fertility begins to fall, because these plants, if harvested and removed, pull nutrients out of the soil. Unlike perennials, they have no evolutionary investment in symbiotic relationships that gradually build up soil fertility and distribution of minerals and other nutrients. So, domesticated annuals cost us fertility of soil. They also tend to cost us the soil structure that enhances water absorption: loss of organic matter. All of "modern" agriculture seeks to counter these problems.

Upon incorporating an ecological model, then, domestication appears as an emergent process, arising as a cultural innovation in response to negative environmental trends due, for the most part, to rising human demand, especially for high producing annual plants. Domestication of many species is the intensified management of desired species to offset negative tropic cascades set off within an ever more constrained land use pattern that happens around settled villages of hunter-gatherers. As wild biomass and diversity diminishes, reliance on a small portfolio of newly "domesticated" species intensifies and hunter-gatherer activities cease to be a viable basis for a way of life in these locations.

\section{Acknowledgements}

None.

\section{Conflict of interest}

Author declares there is no conflict of interest. 